\title{
Inheritance of Resistance to Bacterial Spot Race T4 from Three Tomato Breeding Lines with Differing Resistance Backgrounds
}

\author{
Samuel F. Hutton and Jay W. Scott ${ }^{1}$ \\ Gulf Coast Research and Education Center, Institute of Food and Agricultural Sciences, University \\ of Florida, 14625 CR 672, Wimauma, FL 33598-6101 \\ Jeffrey B. Jones \\ Plant Pathology Department, University of Florida, 2515 Fifield Hall, P.O. Box 110680, Gainesville, \\ FL 32611-0680
}

\begin{abstract}
AdDitional INDEX words. Lycopersicon esculentum, Solanum lycopersicum, Xanthomonas perforans, disease resistance, partial resistance, epistasis

Abstract. Resistance of tomato (Solanum lycopersicum) to bacterial spot race T4 (Xanthomonas perforans) was characterized by generation means analysis (GMA) in three advanced breeding lines: Fla. 8326, Fla. 8233, and Fla. 8517. GMA of Fla. 8326 for two of three seasons (Fall 2006 and Summer 2007) indicated that resistance is mostly dominant with significant additive and epistatic effects. GMA of Fla. 8233 in Spring 2007 and of Fla. 8517 in Summer 2007 also showed dominance to be the main effect in addition to additive and epistatic effects. Duplicate dominance or recessive suppressor type epistasis was indicated in each breeding line. Transgressive segregation was not clearly observed in $F_{2}$ populations of crosses between resistant parents, suggesting that these lines have quantitative trait loci in common.
\end{abstract}

Bacterial spot of tomato is caused by as many as four species of Xanthomonas: X. euvesicatoria, X. vesicatoria, X. perforans, and $X$. gardneri (Jones et al., 2000, 2005); the former three species were previously named $X$. campestris pv. vesicatoria and $X$. vesicatoria (Jones et al., 2006). Optimum temperature for this bacterium's growth is around $27{ }^{\circ} \mathrm{C}$ (Gardner and Kendrick, 1923), and secondary spread of the disease within plant beds and production fields occurs primarily by winddriven rain and surface-drainage of water that contains the bacterium (Sherf and Macnab, 1986). Thus, disease prevalence is greatest when temperatures are high and rainfall is frequent. Symptoms of this disease occur on leaves, stems, and fruit. Severe losses can occur due to leaf infections that cause defoliation, which may result in yield losses and reduced quality from cracking, sunscald, or black shoulder (Scott and Jones, 1986).

Control of bacterial spot is based primarily on the use of bactericides and has become more difficult over the years. Antibiotics, particularly streptomycin, were once very efficacious in controlling the disease, but are no longer used due to the ability of the bacterium to develop resistance (Lai et al., 1977; Stall and Thayer, 1962). Copper formulations proved effective in reducing bacterial spot development (Stall, 1959). However, after years of application, many bacterial strains have developed copper resistance, and these resistant strains are now dominant in Florida (Marco and Stall, 1983). Copper applied in combination with mancozeb has been shown to more effectively control bacterial spot than copper applied alone (Conover and Gerhold, 1981; Marco and Stall, 1983). Current control

Received for publication 2 Feb. 2010. Accepted for publication 9 Mar. 2010. This research was supported in part by The Florida Tomato Committee.

We thank Jerry Minsavage, Cathy Provenzano, and Rosa Ayala for technical assistance.

${ }^{1}$ Corresponding author. E-mail: jwsc@ufl.edu. practices primarily use this latter tank mix, but control is often poor during periods of high disease pressure (Jones and Jones, 1985; Jones et al., 1991a, 1991b).

Alternative methods for controlling bacterial spot are available. Compounds such as acibenzolar-S-methyl (Actigard; Syngenta, Basel, Switzerland) that induce systemic acquired resistance (SAR) in the plant were effective control alternatives (Louws et al., 2001), and acibenzolar-S-methyl is routinely used in northern Florida against bacterial spot on field-grown fresh-market tomato (Obradovic et al., 2005). The use of bacteriophages also helped control bacterial spot of tomato (Balogh et al., 2003; Flaherty et al., 2000) and complemented SAR-inducers when applied as part of an alternative management program (Obradovic et al., 2005).

Much effort has been directed toward breeding for resistant varieties, but development has been difficult due to the limited availability of resistance sources, multigenic control of resistance, and the emergence of new races of the pathogen. Resistance to $X$. euvesicatoria race T1 was identified in Hawaii 7998 (H7998) (Jones and Scott, 1986; Scott and Jones, 1986) and was based on the multigenic nature of a hypersensitive response (HR) (Wang et al., 1994; Whalen et al., 1993; Yu et al., 1995) and on additional genetic factors (Somodi et al., 1996; Wang, 1992). Non-hypersensitive resistance to $X$. vesicatoria race T2 from PI 114490 was reported to be additive and controlled by two genes, where all four alleles were required for maximum resistance (Scott et al., 2003). Strains of $X$. perforans race T3 have been isolated in Florida since 1991 and have been described by Jones et al. (1995). This race was shown to be antagonistic to race $\mathrm{T} 1 \mathrm{in}$ in vitro experiments (Jones et al., 1998a); the race $\mathrm{T} 1$ strain has been largely displaced by race T3 (Jones et al., 1998b). Race T3 overcame the hypersensitivity of H7998, but produced an HR on Hawaii 7981 (H7981). Scott et al. (1995) reported on the hypersensitivity and/or resistance 
of a number of lines to race T3 in 2 years of testing. H7981, PI 126932, and PI 128216 all exhibited an HR; H7981 showed the highest level of resistance, and selections of PI 126932 and PI 128216 had partial resistance. Several PIs, including PI 114490, displayed non-hypersensitive partial resistance. The HR in H7981 was determined to be controlled by an incompletely dominant gene, Xv3 (Scott et al., 1996), but field resistance was determined to be quantitatively conferred by $X v 3$ and other resistance genes (Scott et al., 2001). More recently, $X$. perforans race $\mathrm{T} 4$ has emerged, and has overcome the hypersensitive resistance in H7981, PI 128216, and PI 126932 (Astua-Monge et al., 2000; Minsavage et al., 2003).

Despite these difficulties, host resistance remains an attractive goal for control of bacterial spot. In particular, because races $\mathrm{T} 3$ and T4 are problems in Florida, durable resistance to multiple races is desired. Three advanced breeding lines have been developed that have non-hypersensitive resistance to race T4. Fla. 8233 is a large-fruited fresh-market tomato with PI 128216 and $\mathrm{H} 7998$ in its pedigree; it has a moderate to high level of resistance to race T4. Fla. 8517, with PI 114490, PI 128216, and H7998 in its pedigree, is a plum tomato with moderate to high resistance. Fla. 8326 has PI 126932 and H7998 in its pedigree. It is a large-fruited freshmarket tomato with only a moderate level of resistance. The objective of this research was to determine the inheritance of race T4 resistance from each of these three resistant breeding lines and to investigate the potential for pyramiding resistance quantitative trait loci (QTL).

\section{Materials and Methods}

\section{Experimental design, inoculation, and disease evaluation}

For each experiment, a randomized complete block design was used with four blocks, each with 10 plants per plot for the parent, $F_{1}$, and reciprocal $F_{1}\left(R_{1}\right)$ lines, one plot of 25 plants for the backcross generations, and two plots of 25 plants for the $\mathrm{F}_{2}$ generation. The $\mathrm{RF}_{1}$ was included in each experiment to test for maternal inheritance of resistance. For all experiments, seed were sown in growth rooms in Black Beauty spent coal (Reed Minerals, Highland, IN) and were transplanted $\approx 7$ to $10 \mathrm{~d}$ later to Speedling $®$ trays $\left(3.8 \mathrm{~cm}^{3}\right.$ cell size; Speedling, Sun City, FL) in the greenhouse, where seedlings were grown for an additional 4 weeks. Plants were transplanted to field beds that were $20 \mathrm{~cm}$ high and $81 \mathrm{~cm}$ wide and had been fumigated with $67 \%$ methyl bromide:33\% chloropicrin at $196.1 \mathrm{~kg} \cdot \mathrm{ha}^{-1}$ and were covered with reflective plastic mulch. Plants were spaced $46 \mathrm{~cm}$ apart in rows, with $152 \mathrm{~cm}$ between rows, staked, and tied, and irrigated by drip tape beneath the plastic mulch of each bed.

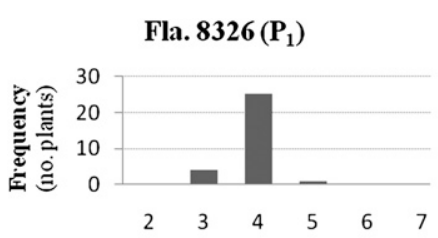

$\begin{array}{ll}4.50 & 4.76 \\ 5.24 & 5.03 \\ 5.20 & 5.29 \\ 6.33 & 5.80 \\ 6.20 & 6.56 \\ 7.92 & 7.83\end{array}$

3.54
3.87
4.19
4.83
5.80
7.40

0.16471

0.66895

0.64450

0.91003

0.89560

0.33821

5.29
7.69

5.80
7.40

4.76

5.03

5.29
5.80

6.56

6.56
7.83

0.18182

0.57303

0.29213

0.95317

0.38986

0.18083

$\begin{gathered}\text { Goodness } \\ \text { of fit }\end{gathered}$
0.019
0.658
0.001
0.972
0.021
0.028
$X^{2}=1.70$
$P=0.64$
0.007
0.633
9.939
2.846
27.515
9.778
$X^{2}=50.72$
$P<0.0001$
8.357
4.127
1.812
47.445
24.335
1.035
$X^{2}=87.11$
$P<0.0001$

$P<0.0001$

Disease severity (1-12 scale)

$\mathrm{F}_{1}$

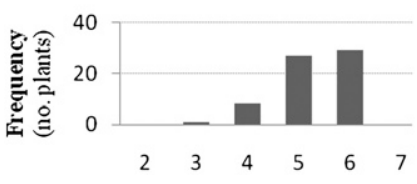

Disease severity (1-12 scale)

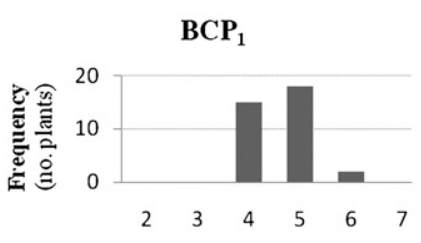

Disease severity (1-12 scale)

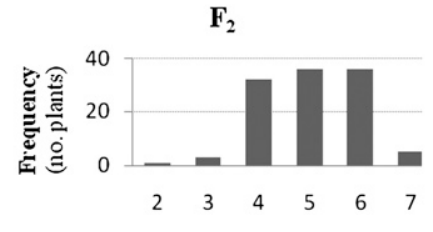

Disease severity (1-12 scale)

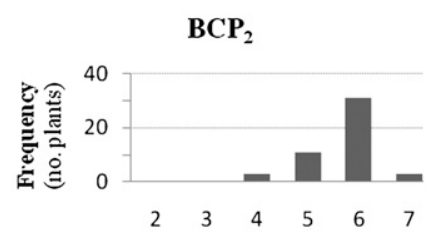

Disease severity (1-12 scale)

Fig. 1. Bacterial spot race T4 disease severity frequency distributions for tomato parents Fla. 8326, Fla. 7946, and generations derived from them at Citra, FL, during Fall 2005 ( $\mathrm{BC}=$ backcross). Plants were rated on the Horsfall-Barratt (1945) scale, where higher numbers indicate more disease. 
A recommended fertilizer program was followed, and plants were sprayed with pesticides (excluding any bactericides) as needed throughout the season (Olson et al., 2007).

Inoculum was produced by growing a strain of $X$. perforans race T4 on Difco nutrient agar (Becton Dickinson and Company, Sparks, MD) for 24 to $36 \mathrm{~h}$ at $28^{\circ} \mathrm{C}$. Bacterial cells were removed from the agar plates and suspended in $10 \mathrm{~mm}$ $\mathrm{MgSO}_{4} \cdot 7 \mathrm{H}_{2} \mathrm{O}$, and the suspensions were standardized to $\mathrm{A}_{600}=0.30$ (a concentration of $\approx 2$ to $5 \times 10^{8} \mathrm{cfu} / \mathrm{mL}$. Inoculum was applied at this concentration without surfactant or was diluted to $\approx 10^{6} \mathrm{cfu} / \mathrm{mL}$ after standardization and applied along with Silwet L-77 surfactant (Helena Chemical, Collierville, $\mathrm{TN})$ at $0.025 \%(\mathrm{v} / \mathrm{v})$ as indicated below. Inoculum was applied by misting the foliage with a backpack sprayer. Plants were rated for disease severity in the field using the Horsfall and Barratt (1945) scale, where $1=0 \%, 2=0 \%$ to $3 \%, 3=3 \%$ to $6 \%, 4=6 \%$ to $12 \%, 5=12 \%$ to $25 \%, 6=25 \%$ to $50 \%, 7=50 \%$ to $75 \%, 8=75 \%$ to $87 \%, 9=87 \%$ to $94 \%, 10=94 \%$ to $97 \%$, $11=97 \%$ to $100 \%$, and $12=100 \%$ diseased tissue. Data were subjected to generation means analysis, and the estimated parameters were used to test for goodness of fit to an additive-dominance model (Mather and Jinks, 1982).

\section{Plant materials}

FLA. 8326. The race T4-susceptible inbred Fla. 7946 was crossed to Fla. 8326, and subsequently, the $F_{1}$ was selfpollinated to produce $F_{2}$ seed and was crossed to each parent to produce backcrosses. These generations were used for inheritance studies in Fall 2005, Spring 2006, and Summer 2007. For the Fall 2005 experiment, seeds were sown on 29 July and were transplanted to the field in Citra, FL, on 9 Sept. Race T4 inoculum (at a concentration of $\approx 2$ to $5 \times 10^{8} \mathrm{cfu} / \mathrm{mL}$ ) was

Table 2. Estimates of additive, dominance, and interaction parameters for the Fla. $8326 \times$ Fla. 7946 tomato family.

\begin{tabular}{lcrrl}
\hline Season & Parameter $^{\mathrm{z}}$ & Estimate $( \pm \mathrm{SE})$ & \multicolumn{2}{c}{$t$ test } \\
\hline Fall 2005 & $\mathrm{m}$ & $4.230 \pm 0.471$ & 8.98 & $* * *$ \\
& {$[\mathrm{~d}]$} & $-1.140 \pm 0.064$ & -17.68 & $*$ \\
& {$[\mathrm{~h}]$} & $1.670 \pm 1.137$ & 1.47 & $\mathrm{NS}$ \\
Spring 2006 & {$[\mathrm{i}]$} & $0.560 \pm 0.467$ & 1.20 & $\mathrm{NS}$ \\
& {$[\mathrm{j}]$} & $0.160 \pm 0.303$ & 0.53 & $\mathrm{NS}$ \\
& {$[\mathrm{l}]$} & $-0.740 \pm 0.700$ & -1.06 & $\mathrm{NS}$ \\
& $\mathrm{m}$ & $6.028 \pm 0.432$ & 13.95 & $* * *$ \\
& {$[\mathrm{~d}]$} & $-2.070 \pm 0.060$ & -34.69 & $* *$ \\
Summer 2007 & {$[\mathrm{h}]$} & $-3.697 \pm 1.091$ & -3.39 & $* *$ \\
& {$[\mathrm{i}]$} & $-0.408 \pm 0.428$ & -0.95 & NS \\
& {$[\mathrm{j}]$} & $1.420 \pm 0.312$ & 4.56 & $* *$ \\
& {$[\mathrm{l}]$} & $2.146 \pm 0.703$ & 3.05 & $* *$ \\
& $\mathrm{~m}$ & $8.662 \pm 0.408$ & 21.24 & $* * *$ \\
& {$[\mathrm{~d}]$} & $-1.710 \pm 0.006$ & -27.21 & $*$ \\
& {$[\mathrm{~h}]$} & $-5.854 \pm 1.006$ & -5.82 & $* *$ \\
& {$[\mathrm{i}]$} & $-2.452 \pm 0.403$ & -6.09 & $* *$ \\
& {$[\mathrm{j}]$} & $1.495 \pm 0.284$ & 5.27 & $* *$ \\
& {$[\mathrm{l}]$} & $2.396 \pm 0.624$ & 3.84 & $* *$ \\
\hline
\end{tabular}

$\overline{{ }^{\mathrm{z}} \mathrm{m}}=$ midpoint (between AA and aa), [d] = difference of AA and aa from midparent, $[\mathrm{h}]=$ difference of Aa from midparent value, [i] = homozygote $\times$ homozygote interaction, [j] homozygote $\times$ heterozygote interaction, [1] heterozygote $\times$ heterozygote interaction.

Ns $, *, * *, * * *$ Not significant or significant at $P \leq 0.05,0.01$, or 0.001 , respectively. applied to the plants early in the morning on 16 Sept., and each plant was rated for disease severity on 19 Oct. For the Spring 2006 experiment, seeds were sown on $17 \mathrm{Feb}$. and were transplanted to the field in Balm, FL, on 29 Mar.; plants were
Fla. $8326\left(\mathbf{P}_{1}\right)$

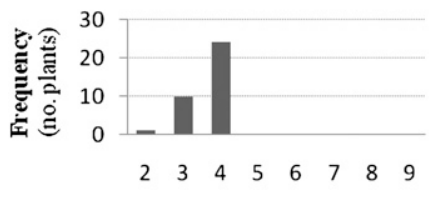

Disease severity (1-12 scale)

$\mathrm{F}_{1}$

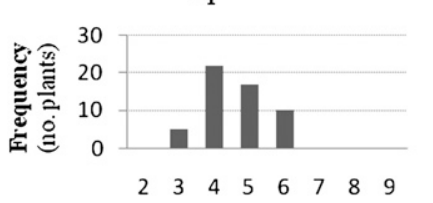

Disease severity (1-12 scale)

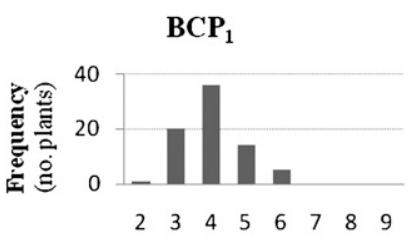

Disease severity (1-12 scale)

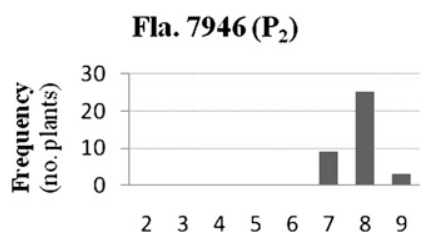

Disease severity (1-12 scale)

$\mathbf{F}_{2}$

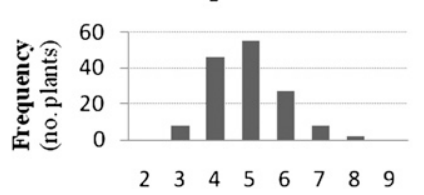

Disease severity (1-12 scale)

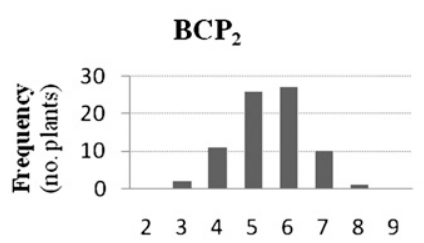

Disease severity (1-12 scale)
Fig. 2. Bacterial spot race T4 disease severity frequency distributions for tomato parents Fla. 8326, Fla. 7946, and generations derived from them at Balm, FL, during Spring $2006(\mathrm{BC}=$ backcross $)$. Plants were rated on the HorsfallBarratt (1945) scale, where higher numbers indicate more disease.
Fla. $8326\left(\mathbf{P}_{1}\right)$
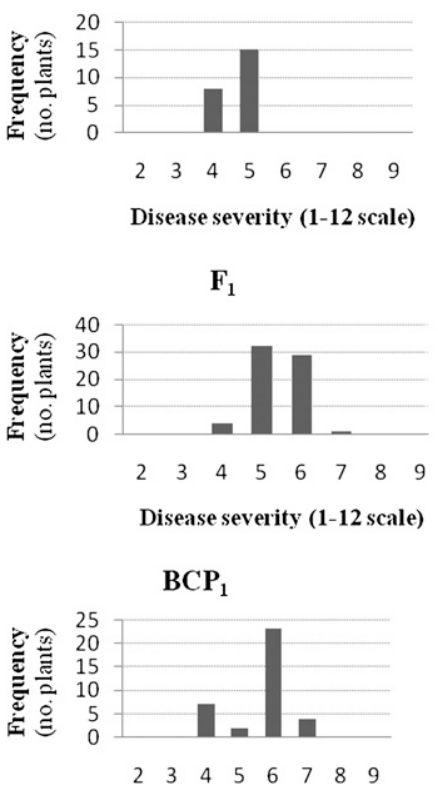

Disease severity (1-12 scale)
Fla. $7946\left(\mathrm{P}_{2}\right)$

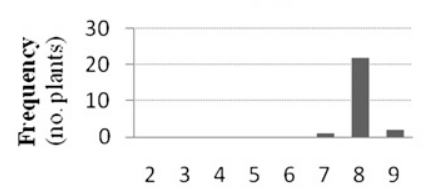

Disease severity (1-12 scale)

$\mathrm{F}_{2}$

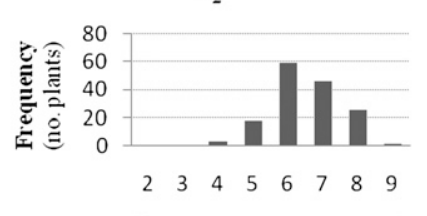

Disease severity (1-12 scale)

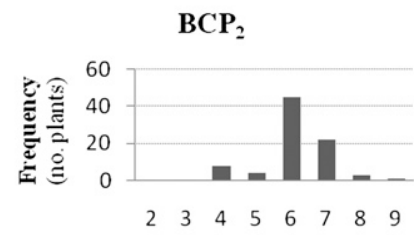

Disease severity (1-12 scale)
Fig. 3. Bacterial spot race T4 disease severity frequency distributions for tomato parents Fla. 8326, Fla. 7946, and generations derived from them at Citra, FL, during Summer 2007 (BC = backcross). Plants were rated on the HorsfallBarratt (1945) scale, where higher numbers indicate more disease. 
naturally infected with race $\mathrm{T} 4$, and each plant was rated for disease severity the week of 26 June. For the Summer 2007 experiment, seeds were sown on 8 June, and race T4 inoculum (at a concentration of $\approx 2$ to $5 \times 10^{6} \mathrm{cfu} / \mathrm{mL}$, plus Silwet-L 77) was applied to plants on 20 July, before transplanting to the field in Citra, FL, on 26 July. Each plant was rated for disease severity on 3 Oct.

FLA. 8233. The race T4-susceptible inbred Fla. 7776 was crossed to Fla. 8233, and generations were produced as above. These generations were used for inheritance studies in Fall 2006, Spring 2007, and Summer 2007. Extremely poor field conditions in Fall 2006 and Summer 2007 made disease severity ratings very difficult and resulted in unreliable data that will not be presented here. For the Spring 2007 experiment, seeds were sown on 1 Feb. and were transplanted to the field in Balm, FL, on 13 Mar. Race T4 inoculum (at a concentration of $\approx 2$ to $5 \times 10^{8} \mathrm{cfu} / \mathrm{mL}$ ) was applied early in the morning on 25 Apr., and each plant was rated for disease severity on 1 May.

FLA. 8517. The race T4-susceptible inbred Fla. 7776 was crossed to Fla. 8517, and generations were produced as above. These generations were used for inheritance studies in Fall 2006, Spring 2007, and Summer 2007. Extremely poor field conditions in Fall 2006 and low disease levels in Spring 2007 made disease severity ratings very difficult and resulted in unreliable data that will not be presented here. For the Summer 2007 experiment, seeds were sown on 8 June, and race T4 inoculum (at a concentration of $\approx 2$ to $5 \times 10^{6} \mathrm{cfu} / \mathrm{mL}$, plus Silwet-L77) was applied to plants on 20 July, before transplanting to the field in Citra, FL, on 26 July. Each plant was rated for disease severity on 3 Oct.

\section{Combined resistance}

Fla. 8233 was crossed to Fla. 8326 , and subsequently, the $F_{1}$ was self-pollinated to produce $\mathrm{F}_{2}$ seed. These generations were included in the Fla.8326 inheritance studies in Citra, FL, in Fall 2005 and in Balm, FL, in Spring 2006. Dates for seed sowing, transplanting, inoculation, and disease evaluation were the same as those stated above for the Fla. 8326 Fall 2005 and Spring 2006 inheritance studies.

Fla. 8326 was crossed to Fla. 8517 , Fla. 8517 was crossed to Fla. 8233, and each $\mathrm{F}_{1}$ was subsequently self-pollinated to produce $F_{2}$ seed. These generations were included in the inheritance study in Summer 2007 in Citra, FL. Seeds were sown on 8 June, and race T4 inoculum (at a concentration of $\approx 2$ to $5 \times$ $10^{6} \mathrm{cfu} / \mathrm{mL}$, plus Silwet-L77) was applied to plants on 20 July, before transplanting to the field on 26 July. Each plant was rated for disease severity on 4 Oct.

Analysis of variance using the GLM procedure of SAS (version 9.1; SAS Institute, Cary, NC) was used to test for differences between $\mathrm{F}_{1}$ and $\mathrm{RF}_{1}$ generations, and for differences between resistant parents.

\section{Results}

In two of the three seasons that Fla. 8326 was tested, the $\mathrm{F}_{1}$ and $\mathrm{RF}_{1}$ did not exhibit any significant difference $(P \leq 0.05)$ in susceptibility to race $\mathrm{T} 4$, indicative of only nuclear inheritance; likewise, maternal inheritance was not indicated in Fla. 8233 or Fla. 8517 (data not shown). Thus, within each family, the $\mathrm{F}_{1}$ and $\mathrm{RF}_{1}$ generations were combined for the generation means analyses.

FLA. 8326. Disease pressure was lower in Fall 2005 than in the Spring 2006 or Summer 2007 experiments, as is evidenced by the higher mean disease severity of Fla. 7946 in each of the latter seasons (Table 1). In 2005, disease severities of the $F_{1}$ and $\mathrm{F}_{2}$ were intermediate between the resistant and susceptible parents and skewed toward the susceptible parent (Fig. 1). The mean of the $\mathrm{BCP}_{1}$ was about equal to the midparent, and the $\mathrm{BCP}_{2}$ mean was about equal to the susceptible parent (Tables 1 and 2). The Fall 2005 data had an acceptable fit to an additivedominance genetic model using the joint scaling test (Mather and Jinks, 1982) (Table 1), with only the additive effect having significance (Table 2). Broad sense heritability was estimated to be 0.66 by the method of Allard (1960); narrow sense

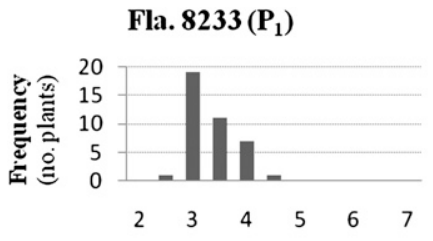

Disease severity (1-12 scale)

$\mathbf{F}_{1}$
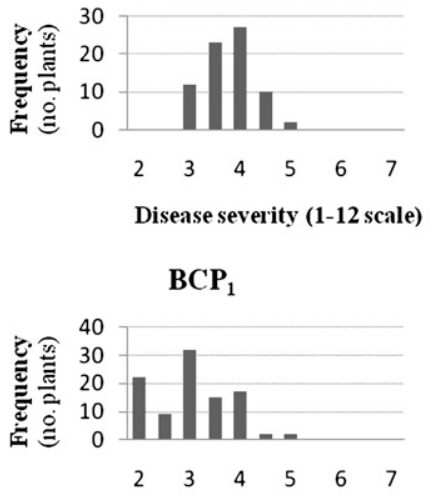

Disease severity (1-12 scale)

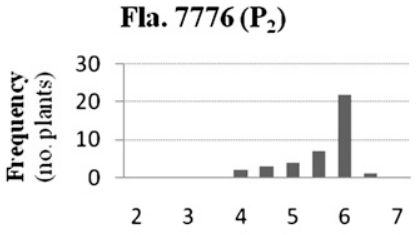

Disease severity (1-12 scale)

$\mathrm{F}_{2}$
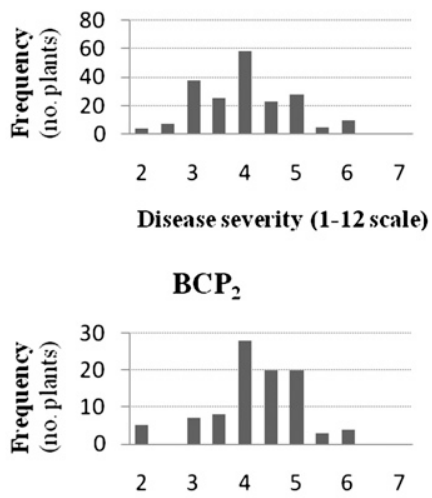

Disease severity (1-12 scale)
Fig. 4. Bacterial spot race T4 disease severity frequency distributions for tomato parents Fla. 8233, Fla. 7776, and generations derived from them at Balm, FL, during Spring 2007 ( $\mathrm{BC}=$ backcross). Plants were rated on the HorsfallBarratt (1945) scale, where higher numbers indicate more disease.

Table 3. Bacterial spot race T4 disease severity for tomato parents Fla. $8233\left(\mathrm{P}_{1}\right)$, Fla. $7776\left(\mathrm{P}_{2}\right)$, and their derived $\mathrm{F}_{1}, \mathrm{~F}_{2}$, and backcross generations in Spring 2007; and joint scaling test for goodness of fit to an additive-dominance model.

\begin{tabular}{lrcccr}
\hline Generation & $\begin{array}{c}\text { Plants } \\
\text { (no.) }\end{array}$ & \multicolumn{2}{c}{ Mean disease severity $(1-12 \text { scale })^{\mathrm{z}}$} & & \multicolumn{2}{c}{$\begin{array}{c}\text { Goodness } \\
\text { of fit }\end{array}$} \\
\cline { 3 - 5 } $\mathrm{P}_{1}$ & 40 & 3.35 & 3.19 & 0.19939 & 4.679 \\
$\mathrm{BCP}_{1}$ & 100 & 3.04 & 3.41 & 0.58929 & 23.465 \\
$\mathrm{~F}_{1}$ & 80 & 3.78 & 3.64 & 0.24156 & 7.245 \\
$\mathrm{~F}_{2}$ & 200 & 3.99 & 3.97 & 0.81716 & 0.086 \\
$\mathrm{BCP}_{2}$ & 100 & 4.23 & 4.53 & 0.73473 & 11.828 \\
$\mathrm{P}_{2}$ & 40 & 5.60 & 5.42 & 0.38394 & 3.342 \\
& & & & & $X^{2}=50.65$ \\
& & & & & $P<0.0001$ \\
\hline
\end{tabular}

${ }^{\mathrm{z}}$ Rated on the Horsfall-Barratt (1945) scale, where higher numbers indicate more disease. 
heritability was estimated at 1.23 by the method of Warner (1952); and the method of Wright (1934) implicated one effective factor contributing to resistance (data not shown).

In Spring 2006, disease severities of the $F_{1}$ and $F_{2}$ were intermediate between the resistant and susceptible parents and skewed toward the resistant parent (Fig. 2). The $\mathrm{BCP}_{1}$ was skewed toward the resistant parent as expected, but the $\mathrm{BCP}_{2}$ segregated in a continuous pattern (Fig. 2) and had a lower mean than the midparent (Tables 1 and 2). In Summer 2007, the $\mathrm{F}_{1}$ and $\mathrm{F}_{2}$ disease severities were intermediate between the resistant and susceptible parents, but the $F_{2}$ mean disease severity was higher than would be expected under an additivedominance model (Fig. 3, Table 1). The $\mathrm{BCP}_{1}$ mean was about equal to that of the $\mathrm{F}_{1}$, while the $\mathrm{BCP}_{2}$ had a lower mean than expected (Table 1). Neither the Spring 2006 nor the Summer 2007 data fit an additive-dominance model due primarily to deviations in the $\mathrm{BCP}_{2}$ generation for both seasons and deviations in the $\mathrm{F}_{2}$ generation in 2007 (Mather and Jinks, 1982) (Table 1).

Thus, an interaction analysis was performed that revealed significant homozygous $\times$ homozygous $\{[i]\}$ interactions in Summer 2007, and significant homozygous $\times$ heterozygous $\{[j]\}$ and heterozygous $\times$ heterozygous $\{[1]\}$ interactions in Spring 2006 and Summer 2007 (Table 2). Because the [h] and [1] parameters had opposite signs, duplicate dominance or recessive suppression type of epistasis was indicated (Mather and Jinks, 1982). Dominance and additivity were significant each season, and dominance had a greater effect. The presence of epistasis and dominance prevented the estimates of effective factors and heritabilities.

In Fall 2005, 36 of $113 \mathrm{~F}_{2}$ plants were as resistant as Fla. 8326 (disease severity $\leq 4$ ), and 41 were as susceptible as Fla. 7946 (disease severity $\geq 6$ ). In Spring 2006, 54 of $146 \mathrm{~F}_{2}$ plants were resistant, while only 10 were susceptible. In Summer 2007,21 of $152 \mathrm{~F}_{2}$ plants were as resistant as Fla. 8326 (disease severity $\leq 5$ ), and 41 were as susceptible as Fla. 7946 (disease severity $\geq 7$ ). Averaged across the three seasons, $\approx 27 \%$ of $\mathrm{F}_{2}$ plants were resistant and 30\% were susceptible.

FLA. 8233. Disease pressure in Spring 2007 was moderate. The disease severities of Fla. 8233 and Fla. 7776 were distinguishable from one another, but there was a low percentage of overlap between the two distributions (Fig. 4). The $F_{1}$ was intermediate between resistant and susceptible parents and skewed toward resistance (Table 3, Fig. 4). The $\mathrm{BCP}_{1}$ had an excess of resistant plants, resulting in a lower mean disease severity than was expected. The $\mathrm{BCP}_{2}$ was distributed between the two parents and was skewed slightly toward susceptibility. The $\mathrm{F}_{2}$ displayed continuous variation between the two parents. An additive-dominance model was not sufficient to explain the data, primarily due to deviations in the backcross generations (Table 3).

An interaction analysis revealed significant homozygous $\times$ homozygous $\{[i]\}$ and heterozygous $\times$ heterozygous $\{[1]\}$ interactions (Table 4). The opposite signs of the [h] and [1] parameters indicated duplicate dominance or recessive suppression type epistasis. Additive and domi- nance effects were also significant, and dominance had the greatest contribution to resistance. The presence of dominance and epistasis prevented an estimation of effective factors and heritabilities.

Of the $198 \mathrm{~F}_{2}$ plants evaluated, $49(25 \%)$ were as resistant as Fla. 8233 with disease severity $\leq 3$. Forty-three $(22 \%)$ were as susceptible as Fla. 7776 with disease severity $\geq 5$.

FLA. 8517. Under moderate to high disease pressure in Summer 2007, parents separated with a small overlap. Mean disease severity of the $F_{1}$ and $F_{2}$ was intermediate between the resistant and susceptible parents, and each was skewed slightly toward susceptible (Table 5, Fig. 5). The backcross to the resistant parent was more susceptible than expected, with a mean disease severity about equal to the $\mathrm{F}_{1}$ and some very susceptible plants, and the $\mathrm{BCP}_{2}$ was slightly less susceptible than the susceptible parent. Because of the observed deviations in the $\mathrm{BCP}_{1}$ generation and, to a lesser extent, in the $\mathrm{F}_{2}$ generation, an additive-dominance model was inadequate to describe the data.

An interaction analysis identified significant, homozygous $\times$ homozygous $\{[i]\}$, homozygous $\times$ heterozygous $\{[j]\}$ and heterozygous $\times$ heterozygous $\{[1]\}$ interactions, and duplicate dominance or recessive suppression type epistasis was indicated as with the other families (Table 6). Dominance and additive effects were significant, and dominance was the primary contributor to resistance.

One hundred sixty-three $\mathrm{F}_{2}$ plants were evaluated in Summer 2007. Of these, $37(23 \%)$ were rated $\leq 4$ and were as

Table 4. Estimates of additive, dominance, and interaction parameters for the Fla. $8233 \times$ Fla. 7776 tomato family in Spring 2007 .

\begin{tabular}{lrrl}
\hline Parameter $^{\mathrm{r}}$ & Estimate $( \pm \mathrm{SE})$ & \multicolumn{2}{c}{$t$ test } \\
\hline $\mathrm{m}$ & $5.901 \pm 0.352$ & -16.75 & $* * *$ \\
{$[\mathrm{~d}]$} & $-1.128 \pm 0.061$ & -6.21 & $*$ \\
$\mathrm{~h}]$ & $-5.529 \pm 0.890$ & -4.11 & $* * *$ \\
{$[\mathrm{i}]$} & $-1.427 \pm 0.347$ & -0.44 & NS \\
{$[\mathrm{j}]$} & $-0.116 \pm 0.264$ & 6.11 & $* * *$ \\
{$[1]$} & $3.413 \pm 0.558$ &
\end{tabular}

${ }^{\mathrm{z}} \mathrm{m}=$ midpoint (between AA and aa), [d] = difference of AA and aa from midparent, $[\mathrm{h}]=$ difference of Aa from midparent value, $[\mathrm{i}]=$ homozygote $\times$ homozygote interaction, [j] homozygote $\times$ heterozygote interaction, and [1] heterozygote $\times$ heterozygote interaction.

Ns $, *, * *, * *$ Not significant or significant at $P \leq 0.05,0.01$, or 0.001 , respectively.

Table 5. Bacterial spot race T4 disease severity for tomato parents Fla. $8517\left(\mathrm{P}_{1}\right)$, Fla. $7776\left(\mathrm{P}_{2}\right), \mathrm{F}_{1}$, $\mathrm{F}_{2}$, and backcross generations in Summer 2007, and joint scaling test for goodness of fit to an additive-dominance model.

\begin{tabular}{|c|c|c|c|c|c|}
\hline \multirow[b]{2}{*}{ Generation } & \multirow{2}{*}{$\begin{array}{c}\text { Plants } \\
\text { (no.) }\end{array}$} & \multicolumn{2}{|c|}{ Mean disease severity (1-12 scale $)^{2}$} & \multirow[b]{2}{*}{ Variance } & \multirow{2}{*}{$\begin{array}{c}\text { Goodness } \\
\text { of fit }\end{array}$} \\
\hline & & Observed & Expected & & \\
\hline$\overline{\mathrm{P}_{1}}$ & 34 & 3.99 & 4.07 & 0.28008 & 0.793 \\
\hline $\mathrm{BCP}_{1}$ & 76 & 5.09 & 4.64 & 0.72259 & 20.785 \\
\hline $\mathrm{F}_{1}$ & 78 & 5.17 & 5.21 & 0.27160 & 0.358 \\
\hline $\mathrm{F}_{2}$ & 163 & 4.99 & 5.20 & 0.63417 & 11.508 \\
\hline $\mathrm{BCP}_{2}$ & 91 & 5.92 & 5.77 & 0.49957 & 4.328 \\
\hline $\mathrm{P}_{2}$ & 34 & 6.32 & 6.33 & 0.33155 & $\begin{array}{c}0.002 \\
X^{2}=37.77 \\
P<0.0001\end{array}$ \\
\hline
\end{tabular}

${ }^{\mathrm{z} R a t e d}$ on the Horsfall-Barratt (1945) scale, where higher numbers indicate more disease. 
Fla. $8517\left(\mathbf{P}_{1}\right)$

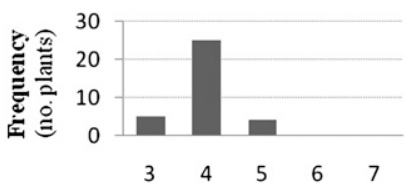

Disease severity (1-12 scale)

$\mathbf{F}_{1}$

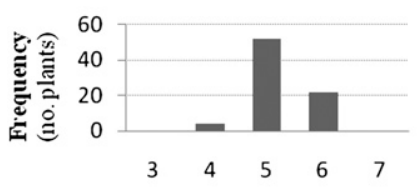

Disease severity (1-12 scale) $\mathrm{BCP}_{1}$

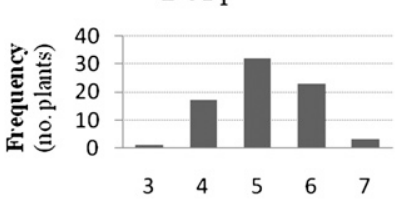

Disease severity (1-12 scale)
Fla. $7776\left(\mathbf{P}_{2}\right)$

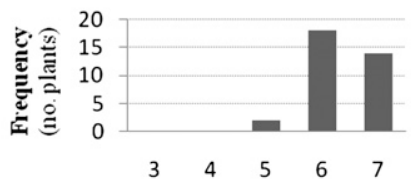

Disease severity (1-12 scale)

$\mathbf{F}_{2}$

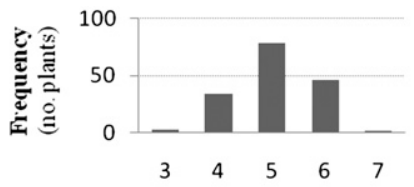

Disease severity (1-12 scale) $\mathrm{BCP}_{2}$

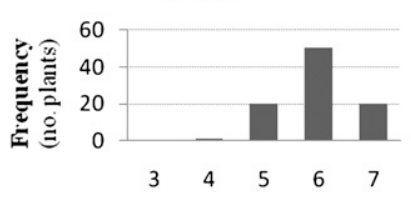

Disease severity (1-12 scale)

Fig. 5. Bacterial spot race T4 disease severity frequency distributions for tomato parents Fla. 8517, Fla. 7776, and generations derived from them at Citra, FL, during Summer 2007 ( $\mathrm{BC}=$ backcross). Plants were rated on the HorsfallBarratt (1945) scale, where higher numbers indicate more disease.

Table 6. Estimates of additive, dominance, and interaction parameters for the Fla. $8517 \times$ Fla. 7776 tomato family in Summer 2007 .

\begin{tabular}{lrrr}
\hline Parameter $^{\mathrm{z}}$ & Estimate $( \pm \mathrm{SE})$ & \multicolumn{2}{c}{$t$ test } \\
\hline $\mathrm{m}$ & $3.100 \pm 0.358$ & -17.17 & $* * *$ \\
{$[\mathrm{~d}]$} & $-1.169 \pm 0.068$ & 5.98 & $* * *$ \\
{$[\mathrm{~h}]$} & $5.489 \pm 0.918$ & 5.85 & $* *$ \\
{$[\mathrm{i}]$} & $2.054 \pm 0.351$ & 2.35 & $*$ \\
{$[\mathrm{j}]$} & $0.663 \pm 0.282$ & -5.87 & $* *$ \\
{$[1]$} & $-3.416 \pm 0.582$ &
\end{tabular}

${ }^{\mathrm{z}} \mathrm{m}=$ midpoint (between AA and aa), [d] = difference of AA and aa from midparent, $[\mathrm{h}]=$ difference of Aa from midparent value, $[\mathrm{i}]=$ homozygote $\times$ homozygote interaction, [j] homozygote $\times$ heterozygote interaction, and [1] heterozygote $\times$ heterozygote interaction.

Ns $, *, * *, * * *$ Not significant or significant at $P \leq 0.05,0.01$, or 0.001 , respectively.

resistant as Fla. 8517, while $48(30 \%)$ were rated $\geq 6$ and were as susceptible as Fla. 7776.

Combined RESistance. In Fall 2005, Fla. 8326 had a lower mean disease severity than Fla. $8233(P=0.0024)$, and in Spring 2006, Fla. 8233 was more resistant than Fla. $8326(P<$ 0.0001 ) (Fig. 6). The $F_{2}$ generation had a mean disease severity intermediate between the two parents in both seasons. The disease severities of $F_{2}$ progeny were slightly skewed toward resistance in 2005 and 2006 and were distributed mainly within the range of the two parents. The $\mathrm{F}_{2}$ distribution included one plant that was rated more resistant than either parent in 2005 and several $F_{2}$ plants in 2006 that were rated slightly more susceptible than either parent.

In Summer 2007, the parents Fla. 8517 and Fla. 8233 were about equal, and several individual plants were rated as susceptible (disease severity $>5$ ) (Fig. 7). The mean disease severity of the $\mathrm{F}_{2}$ generation was similar to that of Fla. 8517. No

FALL 2005

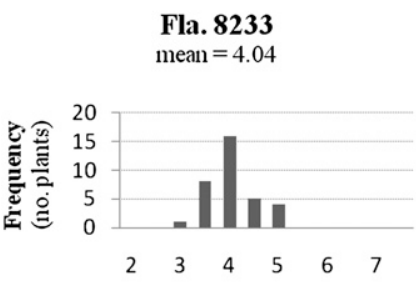

Disease severity (1-12 scale)

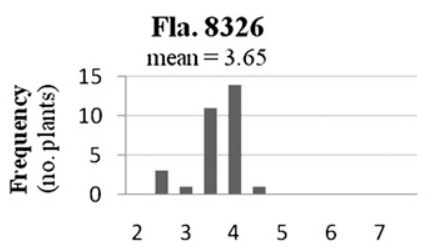

Disease severity (1-12 scale)

$\mathrm{F}_{2}$

mean $=3.76$

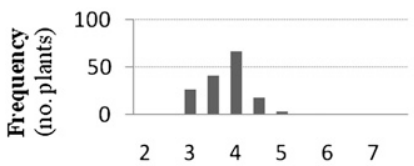

Disease severity (1-12 scale)

Fla. 7946

mean $=6.11$

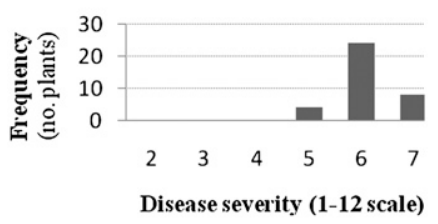

SPRING 2006
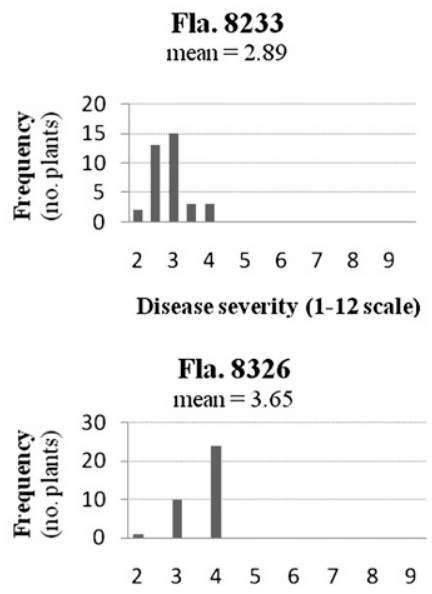

Disease severity (1-12 scale)

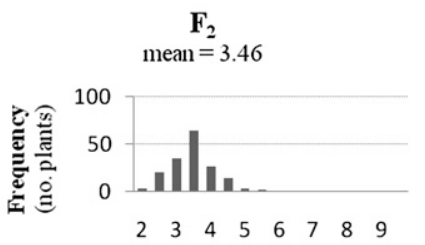

Disease severity (1-12 scale)

Fla. 7946

mean $=7.84$

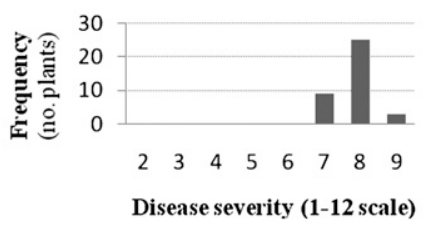

Fig. 6. Bacterial spot race T4 disease severity frequency distributions for tomato parents Fla. 8233, Fla. 8326, the $\mathrm{F}_{2}$ generation derived from them, and Fla. 7946 at Citra, FL, during Fall 2005 and Spring 2006. Plants were rated on the Horsfall-Barratt (1945) scale, where higher numbers indicate more disease.

$\mathrm{F}_{2}$ progeny with greater susceptibility than the parents were observed; however, the $\mathrm{F}_{2}$ distribution included several plants that were less susceptible than either parent.

Fla. 8517 was more resistant than Fla. 8326 in Summer 2007 $(P=0.0002)$ (Fig. 8), and both parents' distributions included individuals rated as susceptible (disease severity $>5$ ). The $F_{2}$ progeny from the cross between these two lines had disease severities that were distributed primarily within the ranges of the two parents and slightly skewed toward Fla. 8326. Of the $130 \mathrm{~F}_{2}$ plants screened, only three were identified as less susceptible than Fla. 8517, and none were more susceptible than either parent.

\section{Discussion}

The University of Florida's tomato breeding program has bred for bacterial spot resistance in the southeast since the early 1980s. The main source of resistance to race T1 from H7998 was overcome in Florida by the emergence of race T3; H7981, PI 126932, and PI 128216 were each identified as resistant to $\mathrm{T} 3$, and all three exhibited race T3 hypersensitivity as well 


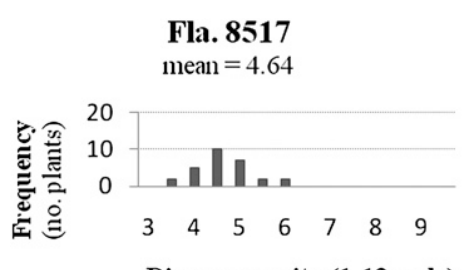

Disease severity (1-12 scale)

Fla. 8233

mean $=4.98$

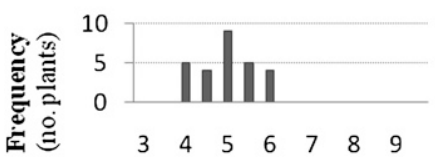

Disease severity (1-12 scale)

$F_{2}$

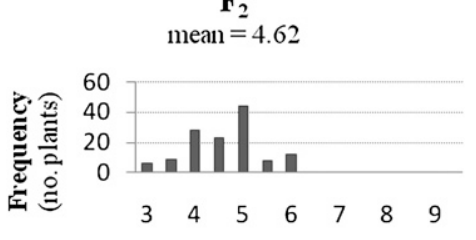

Disease severity (1-12 scale)

Fla. 7946

mean $=8.04$

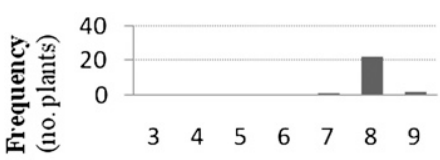

Disease severity (1-12 scale)

Fig. 7. Bacterial spot race T4 disease severity frequency distributions for tomato parents Fla. 8517, Fla. 8233, the $\mathrm{F}_{2}$ generation derived from them, and Fla. 7946 at Citra, FL, during Summer 2007. Plants were rated on the HorsfallBarratt (1945) scale, where higher numbers indicate more disease.

(Jones et al., 1995). Most of the breeding efforts for race T3 resistance focused on H7981 because this line had the highest level of resistance to race T3 (Scott et al., 1995); PI 126932 and PI 128216 were also included in the breeding program, but to a lesser extent. Race T3-resistant breeding lines with these latter sources in their pedigrees include Fla. 8326, Fla. 8233, and one of the parents of Fla. 8517. Each of these three breeding lines also exhibits a non-hypersensitive race T4 resistance, indicating that they may carry loci that confer resistance that is more durable than a traditional hypersensitive resistance. Results from inheritance studies presented in this research indicate that resistance to $X$. perforans race T4 in all three breeding lines is primarily determined by dominant effects, but that epistatic and additive effects also contribute significantly.

Although Fla. 7776 and Fla. 7946 are susceptible to bacterial spot, Fla. 7946 is more susceptible than Fla. 7776. Both lines were used as susceptible parents to study inheritance. Resistant and susceptible individuals were easily distinguished in the Fla. $8326 \times$ Fla. 7946 cross, even in Fall 2005 when disease pressure was low. This is in contrast to crosses involving Fla. 7776, where resistant and susceptible parents still separated, but with a small percentage of overlap.

In Fall 2005, under low disease pressure, Fla. 8326 inheritance data fit an additive-dominance model. However, an
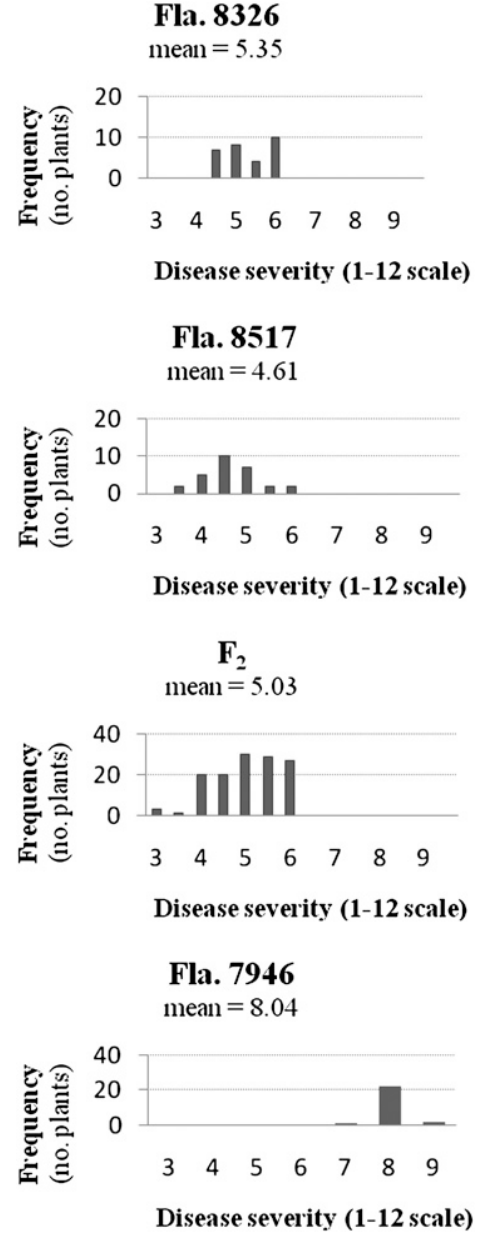

Fig. 8. Bacterial spot race T4 disease severity frequency distributions for tomato parents Fla. 8326, Fla. 8517, the $\mathrm{F}_{2}$ generation derived from them, and Fla. 7946 at Citra, FL, during Summer 2007. Plants were rated on the HorsfallBarratt (1945) scale, where higher numbers indicate more disease.

erroneous narrow-sense heritability was calculated. Two of the assumptions for Warner's (1952) method of calculating this heritability are the absence of dominance and the absence of epistasis. The presence of these effects in Fla. 8326, although undetected in Fall 2005, is possibly the reason for the overestimation of narrow-sense heritability because dominance and epistasis were significant in the Fla. 8326 Spring 2006 and Summer 2007 inheritance studies. Likewise, although a single effective factor was identified in Fall 2005, this estimation is considered inaccurate because the presence of dominance and epistasis violates the assumptions of the model (Wright, 1934).

Combining resistance from various sources is an approach for developing durable resistance, as well as for increasing the level of achievable resistance. Each of the resistant breeding lines used in this study was crossed with each other to determine the potential for pyramiding their resistance genes and to estimate whether these lines had QTL in common. In general, transgressive segregation was not clearly evident: susceptible plants did not segregate from the $F_{2}$ generations of these crosses, and very few plants were identified as more resistant than both parents. Four of the six plants that were rated as more resistant than their parents were selected in Summer 2007 from the $F_{2}$ between Fla. 8517 and Fla. 8233; progeny tests in Fall 2008 did not indicate that these lines were transgressive 
segregates, in that they were not more resistant than Fla. 8517 (data not shown). The lack of segregates with increased levels of resistance over that of the parents suggests that these lines contain common QTL and/or different QTL with similar mechanisms of resistance. However, the lack of susceptible segregates supports the former theory of common QTL in Fla. 8326, Fla. 8233, and Fla. 8517. Consequently, there appears to be limited potential for pyramiding genes from these lines.

As with races T1 (Scott and Jones, 1989) and T3 (Scott et al., 2001), resistance to race T4 appears to be conferred quantitatively. This multigenic control of partial resistance to race $\mathrm{T} 4$ from Fla. 8326, Fla. 8233, and Fla. 8517 presents significant difficulties for developing resistant cultivars. First, this level of partial resistance alone would probably not be sufficient to control bacterial spot under favorable conditions for the disease; nevertheless, it could prove extremely effective when incorporated into an integrated pest management system that uses some of the control measures mentioned previously. Additionally, although the $F_{1}$ was an improvement over the susceptible parent in each study, this would probably not be a commercially acceptable level of resistance. Thus, it will be necessary to incorporate this resistance into both parents of a hybrid. Furthermore, incorporation of this resistance into lines that are not highly susceptible (such as Fla. 7776) will be particularly difficult because progeny with moderate and higher levels of resistance are not easily distinguishable. This, combined with the complicating effects of dominance and epistasis, necessitates the rigorous and repeated evaluation of selections under disease screens to identify plants with higher levels of resistance that are homozygous for resistance alleles.

The efficient and successful deployment of resistance to bacterial spot race T4 depends greatly on the number of QTL effecting resistance and the magnitude of each locus' effect. Each of the resistant breeding lines used in this study has two or more potential donors of resistance alleles in its pedigree, but it is uncertain which alleles are contributing to resistance. The identification of molecular markers linked to resistance loci and their utilization in marker-assisted selection would be extremely useful in applied breeding work to overcome the aforementioned difficulties of incorporating resistance into commercially acceptable material. Such linked markers may also be useful in deciphering which donors provided the race T4 resistance loci, and may facilitate the identification of loci contributing durable resistance. Research toward this end has been conducted and has been successful in identifying candidate QTL and ascertaining the donor of the loci (Hutton, 2008); this work will be the subject of another paper.

\section{Literature Cited}

Allard, R.W. 1960. Principles of plant breeding. Wiley, New York. Astua-Monge, G., G.V. Minsavage, R.E. Stall, M.J. Davis, U. Bonas, and J.B. Jones. 2000. Resistance of tomato and pepper to T3 strains of Xanthomonas campestris pv. vesicatoria is specified by a plantinducible avirulence gene. Mol. Plant Microbe Interact. 13:911-921. Balogh, B., J.B. Jones, M.T. Momol, S.M. Olson, A. Obradovic, P. King, and L.E. Jackson. 2003. Improved efficacy of newly formulated bacteriophages for management of bacterial spot on tomato. Plant Dis. 87:949-954.

Conover, R.A. and N.R. Gerhold. 1981. Mixtures of copper and maneb or mancozeb for control of bacterial spot of tomato and their compatibility for control of fungus diseases. Proc. Florida State Hort. Soc. 94:154-156.
Flaherty, J.E., J.B. Jones, B.K. Harbaugh, G.C. Somodi, and L.E. Jackson. 2000. Control of bacterial spot on tomato in the greenhouse and field with H-mutant bacteriophages. HortScience 35:882-884.

Gardner, M.W. and J.B. Kendrick. 1923. Bacterial spot of tomato and pepper. Phytopathology 13:307-315.

Horsfall, J.G. and R.W. Barratt. 1945. An improved grading system for measuring plant diseases. Phytopathology 35:655.

Hutton, S.F. 2008. Inheritance and mapping of resistance to bacterial spot race T4 (Xanthomonas perforans) in tomato, and its relationship to race T3 hypersensitivity, and inheritance of race T3 hypersensitivity from PI 126932. PhD Diss., Univ. Florida, Gainesville.

Jones, J.B. and J.P. Jones. 1985. The effect of bactericides, tank mixing time and spray schedule on bacterial leaf spot of tomato. Proc. Florida State Hort. Soc. 98:244-247.

Jones, J.B. and J.W. Scott. 1986. Hypersensitive response in tomato to Xanthomonas campestris pv. vesicatoria. Plant Dis. 70:337-339.

Jones, J.B., G.H. Lacy, and H. Bouzar. 2006. Reclassification of the xanthomonads associated with bacterial spot disease of tomato and pepper. Syst. Appl. Microbiol. 29:85-86.

Jones, J.B., G.H. Lacy, H. Bouzar, G.V. Minsavage, R.E. Stall, and N.W. Schaad. 2005. Bacterial spot-worldwide distribution, importance and review. Acta Hort. 695:27-33.

Jones, J.B., H. Bouzar, G.C. Somodi, R.E. Stall, K. Pernezny, G. E1-Morsy, and J.W. Scott. 1998a. Evidence for the preemptive nature of tomato race 3 of Xanthomonas campestris pv. vesicatoria in Florida. Phytopathology 88:33-38.

Jones, J.B., H. Bouzar, R.E. Stall, E.C. Almira, P.D. Roberts, B.W. Bowen, J. Sudberry, P.M. Strickler, and J. Chun. 2000. Systematic analysis of xanthomonads (Xanthomonas spp.) associated with pepper and tomato lesions. Intl. J. Syst. Evol. Microbiol. 50:12111219.

Jones, J.B., R.E. Stall, and H. Bouzar. 1998b. Diversity among Xanthomonads pathogenic on pepper and tomato. Annu. Rev. Phytopathol. 36:41-58.

Jones, J.B., R.E. Stall, J.W. Scott, G.C. Somodi, H. Bouzar, and N.C. Hodge. 1995. A third tomato race of Xanthomonas campestris pv. vesicatoria. Plant Dis. 79:395-398.

Jones, J.B., S.S. Woltz, J.P. Jones, and K.L. Portier. 1991a. Population dynamics of Xanthomonas campestris pv. vesicatoria on tomato leaflets treated with copper bactericides. Phytopathology 81:714719.

Jones, J.B., S.S. Woltz, R.O. Kelly, and G. Harris. 1991b. The role of ionic copper, total copper, and select bactericides on control of bacterial spot of tomato. Proc. Florida. State Hort. Soc. 104:257-259.

Lai, M., N.J. Panopoulos, and S. Shaffer. 1977. Transmission of R plasmids among Xanthomonas spp. and other plant pathogenic bacteria. Phytopathology 67:1044-1050.

Louws, F.J., M. Wilson, H.L. Campbell, D.A. Cuppels, J.B. Jones, P.B. Showemaker, F. Sahin, and S.A. Miller. 2001. Field control of bacterial spot and bacterial speck of tomato using a plant activator. Plant Dis. 85:481-488.

Marco, G.M. and R.E. Stall. 1983. Control of bacterial spot of pepper initiated by strains of Xanthomonas campestris pv. vesicatoria that differ in sensitivity to copper. Plant Dis. 67:779-781.

Mather, K. and J.L. Jinks. 1982. Biometrical genetics: The study of continuous variation. 3rd ed. Chapman and Hall, London.

Minsavage, G.V., B. Balogh, R.E. Stall, and J.B. Jones. 2003. New tomato races of Xanthomonas campestris pv. vesicatoria assoiated with mutagenesis of tomato race 3 strains. Phytopathology 93:S62 (Abstr.).

Obradovic, A., J.B. Jones, M.T. Momol, S.M. Olson, L.E. Jackson, B. Balogh, K. Guven, and F.B. Iriarte. 2005. Integration of biological control agents and systemic acquired resistance inducers against bacterial spot of tomato. Plant Dis. 89:712-716.

Olson, S.M., W.M. Stall, M.T. Momol, S.E. Webb, T.G. Taylor, S.A. Smith, E.H. Simonne, and E. McAvoy. 2007. Tomato production in Florida, p. 409-428. In: S.M. Olson and E. Simonne (eds.). Vegetable 
production handbook for Florida. Inst. Food Agr. Sci., Univ. Florida, Gainesville.

Scott, J.W. and J.B. Jones. 1986. Sources of resistance to bacterial spot [Xanthomonas campestris pv. vesicatoria (Doidge) Dye] in tomato. HortScience 21:304-306.

Scott, J.W. and J.B. Jones. 1989. Inheritance of resistance to foliar bacterial spot of tomato incited by Xanthomonas campestris pv. vesicatoria. J. Amer. Soc. Hort. Sci. 114:111-114.

Scott, J.W., D.M. Francis, S.A. Miller, G.C. Somodi, and J.B. Jones. 2003. Tomato bacterial spot resistance derived from PI 114490; inheritance of resistance to race T2 and relationship across three pathogen races. J. Amer. Soc. Hort. Sci. 128:698-703.

Scott, J.W., J.B. Jones, and G.C. Somodi. 2001. Inheritance of resistance in tomato to race $\mathrm{T} 3$ of the bacterial spot pathogen. $\mathrm{J}$. Amer. Soc. Hort. Sci. 126:436-441.

Scott, J.W., J.B. Jones, G.C. Somodi, and R.E. Stall. 1995. Screening tomato accessions for resistance to Xanthomonas campestris pv. vesicatoria, race T3. HortScience 30:579-581.

Scott, J.W., R.E. Stall, J.B. Jones, and G.C. Somodi. 1996. A single gene controls the hypersensitive response of Hawaii 7981 to race 3 (T3) of the bacterial spot pathogen. Rpt. Tomato Genet. Coop. 46:23. Sherf, A.F. and A.A. Macnab. 1986. Vegetable diseases and their control. 2nd ed. Wiley, New York.

Somodi, G.C., J.B. Jones, J.W. Scott, J.F. Wang, and R.E. Stall. 1996. Relationship between the hypersensitive reaction and field resistance to tomato race 1 of Xanthomonas campestris pv. vesicatoria. Plant Dis. 80:1151-1154.

Stall, R.E. 1959. An evaluation of spray materials for control of bacterial spot on field seeded tomatoes. Plant Dis. Rptr. 43:725-728.

Stall, R.E. and P.L. Thayer. 1962. Streptomycin resistance of the bacterial spot pathogen and control with streptomycin. Plant Dis. Rptr. 46:389-392.

Wang, J.F. 1992. Resistance to Xanthomonas campestris pv. vesicatoria in tomato. PhD Diss., Univ. Florida, Gainesville.

Wang, J.F., J.B. Jones, J.W. Scott, and R.E. Stall. 1994. Several genes in Lycopersicon esculentum control hypersensitivity to Xanthomonas campestris pv. vesicatoria. Phytopathology 84:702-706.

Warner, J.N. 1952. A method for estimating heritability. Agron. J. 44:427-430.

Whalen, M.C., J.F. Wang, F.M. Carland, M.E. Heiskell, D. Dahlbeck, G.V. Minsavage, J.B. Jones, J.W. Scott, R.E. Stall, and B.J. Staskawicz. 1993. Avirulence gene avrRxv from Xanthomonas campestris pv. vesicatoria specifies resistance on tomato line Hawaii 7998. Mol. Plant Microbe Interact. 6:616-627.

Wright, S. 1934. The results of crosses between inbred strains of guinea pigs, differing in number of digits. Genetics 19:537-551.

Yu, Z.H., J.F. Wang, R.E. Stall, and C.E. Vallejos. 1995. Genomic localization of genes that control a hypersensitive reaction to Xanthomonas campestris pv. vesicatoria (Doidge)Dye. Genetics 141:675-682. 